\title{
THE EFFECT OF MANGANESE ON OLIVINE-QUARTZ-ORTHOPYROXENE STABILITY
}

\author{
STEVEN R. BOHLEN ${ }^{*}$, ARTHUR L. BOETTCHER ${ }^{2}$, WAYNE A. DOLLASE $^{3}$ \\ and ERIC J. ESSENE ${ }^{1}$ \\ 1 Department of Geology and Mineralogy, University of Michigan, Ann Arbor, MI 48104 (U.S.A.) \\ 2 Institute of Geophysics and Planetary Physics and Department of Earth and Space Sciences, University of \\ California at Los Angeles, Los Angeles, CA 90024 (U.S.A.) \\ ${ }^{3}$ Department of Earth and Space Sciences, University of California at Los Angeles, Los Angeles, CA 90024 (U.S.A.)
}

Received March 19, 1979

Revised version received October 23, 1979

\begin{abstract}
The effect of manganese on the stability of ferrosilite relative to fayalite + quartz has been experimentally determined to assess its importance to orthopyroxene barometry. Reaction reversals in a piston-cylinder apparatus were obtained to within 0.1 -kbar intervals indicating instability of $\mathrm{Fs}_{95} \mathrm{Rh}_{5}$ below $10.3,10.9,11.4,12.2,12.9,13.7$ kbar and $F_{s_{90}} \mathrm{Rh}_{10}$ below $9.8,10.4,10.9,11.6,12.4$ and 13.2 kbar at $750,800,850,900,950$ and $1000^{\circ} \mathrm{C}$, respectively. Each mole $\% \mathrm{MnSiO}_{3}$ extends the pyroxene stability by approximately 0.12 kbar relative to $\mathrm{FeSiO}_{3}$. $\mathrm{Electron}$ microprobe analyses of run products indicate a small preference of $\mathrm{Mn}$ for pyroxene over olivine with $K_{D \mathrm{Mn}}^{\mathrm{opx}-\mathrm{Fe}}=$ 1.2-1.5, similar to values observed for natural pairs. Mössbauer spectra are consistent with a random distribution of $\mathrm{Mn}$ between the M1 and M2 sites in the orthopyroxene. These experimental data allow downward revision of pressure estimates based on the orthopyroxene barometer in areas where $\mathrm{Mn}$ is a significant component in orthopyroxene.
\end{abstract}

\section{Introduction}

Reactions involving minerals with solid solutions have long been recognized for their potential in determining or limiting pressure and temperature. Minor components can shift the stabilities of reactants and products of a solid-solid reaction over a wide range of pressures and temperatures. Theoretically, these types of reactions should be much more useful than univariant or nearly univariant that result from limited solid solution. Unfortunately, there are rarely sufficient activity data available to allow calculation of the effect of additional components on a given reac-

* Present address: Institute of Geophysics and Planetary Physics, University of California, Los Angeles, Los Angeles, CA 90024, U.S.A.

Institute of Geophysics and Planetary Physics Publication No. 1885. Mineralogy Laboratory, University of Michigan, Contribution No. 348 . tion boundary, and the usefulness of many potential barometers and thermometers is greatly reduced unless experimental data can be obtained. It has been shown in the previous paper [1] that the reaction olivine + quartz $\leftrightarrows$ orthopyroxene is of potential use as a geobarometer, but activity data are unavailable or insufficiently well refined to unambiguously calculate the effects of solid solutions. Order-of-magnitude calculations suggest that additional components can extend the stability of pyroxene to lower pressures. Smith $[2,3]$ experimentally investigated the effect of $\mathrm{MgO}$ in olivine and in orthopyroxene in the system $\mathrm{Mg}_{2} \mathrm{SiO}_{4}-\mathrm{Fe}_{2} \mathrm{SiO}_{4}-\mathrm{SiO}_{2}$. He showed that 30 mole \% $\mathrm{MgSiO}_{3}$ stabilizes the pyroxene over olivine + quartz at $900^{\circ} \mathrm{C}$ and atmospheric pressure; in the $\mathrm{Mg}$-free system (at $900^{\circ} \mathrm{C}$ ), ferrosilite is stable only above 12.6 kbar [1]. Other components including $\mathrm{Mn}, \mathrm{Ca}$, $\mathrm{Na}, \mathrm{Al}, \mathrm{Ti}$, and $\mathrm{Fe}^{3+}$ will also probably enhance pyroxene stability, because they are preferentially concentrated in the pyroxene. $\mathrm{MnSiO}_{3}$ is a major 
impurity in some natural Fe-rich orthopyroxenes, such as at Lofoten, Norway [4], where it is the most significant additional component. Consequently, the writers have undertaken piston-cylinder experiments to calibrate the effects of 5 and 10 mole $\%$ rhodonite solid solution on the stability of Fe-rich ortho-

pyroxene.

\section{Experimental methods}

With a few exceptions the experimental methods used in this study are identical to those described in detail in the previous paper. Starting materials were prepared from electrolytically reduced iron powder, synthetic $\mathrm{Mn}_{3} \mathrm{O}_{4}$ and Brazilian quartz. Equimolar mixtures of fayalite ${ }_{95}$ tephroite $_{5}+$ quartz and fayalite $_{90}$ tephroite $_{10}+$ quartz were synthesized in a
$\mathrm{CO}_{2} / \mathrm{H}_{2}$ gas-mixing furnace and served as one set of starting materials. $\mathrm{Fa}_{95} \mathrm{Te}_{5}+$ quartz and $\mathrm{Fa}_{90} \mathrm{Te}_{10}$ quartz were reacted in a piston-cylinder device $(20$ kbar, $900^{\circ} \mathrm{C}, 1-2$ wt. $\% \mathrm{H}_{2} \mathrm{O}$ ) to synthesize ferrosilite $_{95}$ rhodonite $_{5}$ and ferrosilite ${ }_{90}$ rhodonite $_{10}$, respectively. These served as the other set of starting materials. Starting materials were analyzed by optical, $\mathrm{X}$-ray, electron microprobe and Mössbauer techniques to insure that they were stoichiometric and homogeneous. The experimental apparatus, furnace assemblies, capsules, run procedures and criteria for reaction direction for the piston-cylinder experiments are also identical to those discussed in the previous paper. For most runs (see Table 1 and 2 for run data) equimolar mixtures of $\mathrm{Fs}_{95} \mathrm{Rh}_{5}-\mathrm{Fa}_{95} \mathrm{Te}_{5}+$ quartz and $\mathrm{Fs}_{90} \mathrm{Rh}_{10}-\mathrm{Fa}_{90} \mathrm{Te}_{10}+$ quartz were used for determination of the 5 and 10 mole \% boundaries respectively. To reverse the $K_{D}$, an initially high- $K_{D}$ starting

TABLE 1

Run data ( 5 mole $\% \mathrm{Mn}_{2} \mathrm{SiO}_{4}, \mathrm{MnSiO}_{3}$ )

\begin{tabular}{|c|c|c|c|c|}
\hline Run No. & $T\left({ }^{\circ} \mathrm{C}\right)$ & $P$ (kbar) & $\begin{array}{l}\text { Duration } \\
\text { (hours) }\end{array}$ & Products \\
\hline 62 & 750 & 10.5 & 26.3 & $o p x+$ oliv $+\mathrm{qtz}$ \\
\hline 64 & 750 & 10.3 & 24 & $o p x+$ oliv $+q t z$ \\
\hline 67 & 750 & 10.2 & 23.5 & $o l i v+q t z+o p x$ \\
\hline 55 & 800 & 11.0 & 23.5 & $o p x+($ oliv $+q t z)$ \\
\hline 58 & 800 & 10.8 & 24 & oliv $+q t z+(o p x)$ \\
\hline 61 & 800 & 10.9 & 24 & oliv $+q t z+o p x$ \\
\hline 63 & 850 & 11.5 & 24 & $o p x+($ oliv $+q t z)$ \\
\hline 70 & 850 & 11.4 & 24 & $o l i v+q t z+(\mathrm{opx})$ \\
\hline 54 & 900 & 12.0 & 24 & $o l i v+q t z+(o p x)$ \\
\hline 57 & 900 & 12.2 & 24 & $o l i v+q t z+o p x$ \\
\hline $1133 *$ & 900 & 12.2 & 10 & $o l i v+q t z+o p x$ \\
\hline 60 & 900 & 12.3 & 24 & $o p x+(o l i v+q t z)$ \\
\hline 65 & 950 & 13.1 & 19 & $o p x+(o l i v+q t z)$ \\
\hline 68 & 950 & 12.9 & 19.5 & $o p x+$ oliv $+q t z$ \\
\hline 69 & 950 & 12.8 & 22.5 & oliv $+q t z+o p x$ \\
\hline 37 & 1000 & 12.5 & 27 & $o l i v+q t z$ \\
\hline 40 & 1000 & 12.9 & 22 & $a l i v+q t z$ \\
\hline 48 & 1000 & 13.2 & 24 & $o l i v+q t z+(o p x)$ \\
\hline 50 & 1000 & 13.5 & 23 & $o l i v+q t z+(\mathrm{opx})$ \\
\hline 51 & 1000 & 13.4 & 21.5 & $o l i v+q t z+(o p x)$ \\
\hline 52 & 1000 & 13.6 & 24 & $o l i v+q t z+o p x$ \\
\hline 56 & 1000 & 13.7 & 22.5 & $o l i v+q t z+o p x$ \\
\hline 59 & 1000 & 13.8 & 25 & $o p x+($ oliv $+q t z)$ \\
\hline
\end{tabular}

Italics show the dominant phase(s).

Parentheses indicate very minor to trace amounts.

* Starting material was equal-weight mixture of $\mathrm{Fe}_{1.80} \mathrm{Mn}_{0.20} \mathrm{Si}_{2} \mathrm{O}_{6}$ and $\mathrm{Fa}_{100}\left(+\mathrm{SiO}_{2}\right)$. 
TABLE 2

Run data (10 mole $\% \mathrm{Mn}_{2} \mathrm{SiO}_{4}, \mathrm{MnSiO}_{3}$ )

\begin{tabular}{|c|c|c|c|c|}
\hline Run No. & $T\left({ }^{\circ} \mathrm{C}\right)$ & $P$ (kbar) & $\begin{array}{l}\text { Duration } \\
\text { (hours) }\end{array}$ & Products \\
\hline 77 & 750 & 9.5 & 23.5 & oliv $+q t z+(o p x)$ \\
\hline 80 & 750 & 9.9 & 24 & $o p x+$ oliv $+q t z$ \\
\hline 84 & 750 & 9.8 & 24 & oliv $+q t z+o p x$ \\
\hline 1152 & 750 & 23.0 & 193 & $o p x+\mathrm{qtz}$ \\
\hline 72 & 800 & 10.3 & 24 & $o l i v+q t z+(o p x)$ \\
\hline 79 & 800 & 10.5 & 23.5 & $o p x+$ oliv $+\mathrm{qtz}$ \\
\hline 83 & 800 & 10.4 & 23.5 & oliv $+q t z+(o p x)$ \\
\hline 95 & 850 & 11.0 & 24 & $o p x+($ oliv $+q t z)$ \\
\hline 96 & 850 & 10.8 & 21.5 & oliv $+q t z+(\mathrm{opx})$ \\
\hline 73 & 900 & 11.7 & 21 & $o p x+($ oliv $+q t z)$ \\
\hline 78 & 900 & 11.5 & 29 & oliv $+q t z+(\mathrm{opx})$ \\
\hline 87 & 900 & 11.6 & 22 & $o p x+$ oliv $+q t z$ \\
\hline 76 & 950 & 12.4 & 22.5 & $o p x+($ oliv $+q t z)$ \\
\hline 82 & 950 & 12.2 & 22 & oliv $+q t z+(\mathrm{opx})$ \\
\hline 86 & 950 & 12.3 & 24 & $o l i v+q t z+o p x$ \\
\hline 75 & 1000 & 13.3 & 23 & $o p x+($ oliv $+\mathrm{qtz})$ \\
\hline 81 & 1000 & 13.0 & 19 & $o l i v+q t z+(o p x)$ \\
\hline 85 & 1000 & 13.2 & 23 & $o p x+$ oliv $+\mathrm{qtz}$ \\
\hline
\end{tabular}

Italics show dominant phase(s).

Parentheses indicate very minor to trace amounts.

material $\left(\mathrm{Fs}_{90} \mathrm{Rh}_{10}-\mathrm{Fa}_{100}+\right.$ quartz) of average composition $\mathrm{Fs}_{95} \mathrm{Rh}_{5}$ was used. Microprobe analyses of run products were obtained using equipment and techniques described in the previous paper. The analyses are listed in Tables 3 and 4 . Each analysis represents an average of $4-5$ points taken on different grains in each run product. Maximum deviations among the points within a single analysis were less than $1.5-2 \%$ of the amount present for each element analyzed.

Mössbauer spectra of a few powdered run products were obtained at room temperature using a constant acceleration, mechanically driven Mössbauer spectrometer. Samples of 50-100 mg were used with a 10 $\mathrm{mCi}{ }^{57} \mathrm{Co}$ in Pd source. Duplicate spectra were recorded in 512 channels of a multichannel analyzer using a velocity increment of $0.03 \mathrm{~mm}$ per second per channel. Counting times were sufficient to obtain several million counts per channel and peak dips on the order of $10^{5}$ counts. The spectra were fit with lorentzian doublets constrained to equal widths for the low- and high-velocity components. Chi-squared and additional goodness-of-fit parameters suggested by Ruby [15] were calculated for each fitted spectrum.

\section{Experimental results and discussion}

The effect of 5 and 10 mole \% rhodonite solid solution on the stability of ferrosilite has been calibrated at $50^{\circ} \mathrm{C}$ intervals from 750 to $1000^{\circ} \mathrm{C}$, and the results are shown in Figs. 1 and 2. For comparison, the end-member reaction boundary is also shown. It can be seen that 5 and 10 mole $\%$ rhodonite extend the stability of the pyroxene by nearly 0.6 and 1.2 kbar, respectively, relative to fayalitic olivine + quartz. All three reaction boundaries change slope from approximately $\mathrm{d} \boldsymbol{P} / \mathrm{d} \boldsymbol{T}=10 \mathrm{bar} /{ }^{\circ} \mathrm{C}$ to $\mathrm{d} \boldsymbol{P} / \mathrm{d} \boldsymbol{T}=15 \mathrm{bar} /$ ${ }^{\circ} \mathrm{C}$, where they intersect the $\alpha-\beta$ quartz transition. Our indirect location of the $\alpha-\beta$ quartz transition agrees well with the determination of Cohen and Klement [5]. We have obtained microprobe analyses of run products of coexisting orthopyroxene and olivine to determine the partitioning of manganese. The analyses are compiled in Tables 3 and 4 , and the 


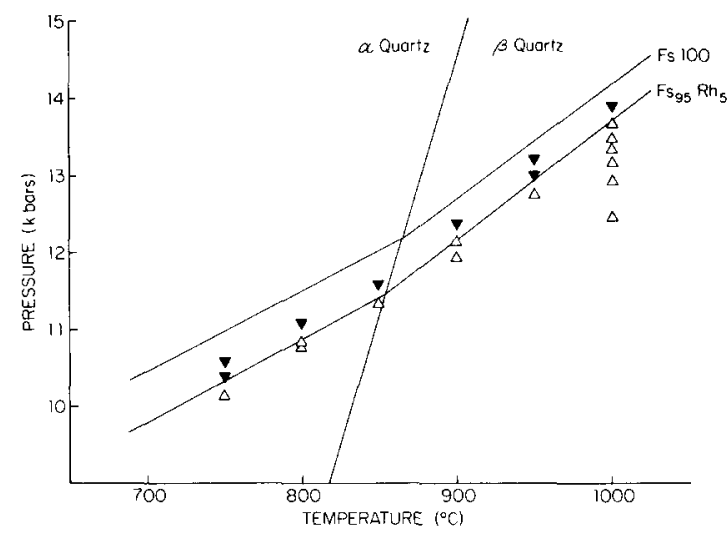

Fig. 1. P-T projection showing the effect of 5 mole \% rhodonite solid solution on Fe-rich pyroxene stability. $\nabla$ indicates that pyroxene grew from olivine + quartz. $\triangle$ indicates that olivine + quart $z$ formed from pyroxene breakdown. The ferrosilite stability [1] is shown for reference.

compositions of coexisting phases are represented graphically in Fig. 3. At $900^{\circ} \mathrm{C}$ we have reversed the $K_{D} *$ (runs 57 and 1133 , Table 1 ) by using initially low- $K_{D}$ and high- $K_{D}$ starting materials in runs at the same $P$-T. The $K_{D}$ at $900^{\circ} \mathrm{C}$ is constrained between $K_{D}^{\mathrm{opx} \text {-oliv }}=1.2-1.5$, consistent with most natural Fe-rich orthopyroxene-olivine pairs [6-8]. At other temperatures half-reversals of $K_{D}$ indicate that the $K_{D}^{\text {opx-oliv }}$ is greater than 1.15 in all but one of the temperatures investigated. We have also obtained Mössbauer spectra to determine any cation ordering in our experimental products. This amounts to determining the intracrystalline $K_{D}$ which, together with the intercrystalline $K_{D}$, are important parameters when attempting to thermodynamically model this system.

Mössbauer spectra were obtained on five orthopyroxene samples synthesized in 24-hour runs at 20$23 \mathrm{kbar}$, and having $\mathrm{MnSiO}_{3}$ components of $0 \%$ $\left(900^{\circ} \mathrm{C}\right), 5 \%\left(750\right.$ and $\left.900^{\circ} \mathrm{C}\right)$ and $10 \%(750$ and $900^{\circ} \mathrm{C}$ ). The limit of detectability of $\mathrm{Fe}^{3+}$ in these samples under the measurement conditions employed

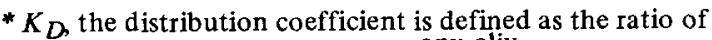
cations in coexisting minerals. $K_{D}^{\text {opx }} \mathrm{Mn}$-Fe reflects the relative proportions of $\mathrm{Mn}$ and $\mathrm{Fe}$ in orthopyroxene and olivine and is calculated: $K_{D}^{\mathrm{opx}-o l i v}=\left[\mathrm{Mn}^{\mathrm{opx}} / \mathrm{Fe}^{\mathrm{opx}}\right]\left[\mathrm{Fe}^{\text {oliv }} /\right.$ $\mathrm{Mn}^{\text {oliv }}$ ].
}

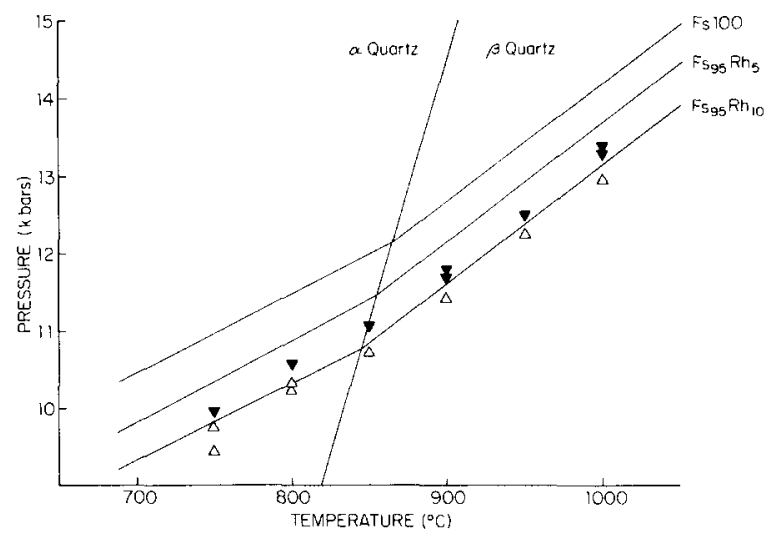

Fig. 2. $P-T$ projection showing the effect of 10 mole $\%$ rhodonite solid solution on Fe-rich pyroxene stability. Symbols indicate reaction direction as in Fig. 1. For reference the stability curves for ferrosilite and ferrosilite -5 mole \% rhodonite are shown.

is estimated as less than $1 \%$ of the iron present and no $\mathrm{Fe}^{3+}$ was detected in any sample. The 10 mole $\%$ samples showed $1-2 \%$ of the iron to be present in an impurity phase, apparently garnet. Other than this minor component, the samples were single-phase orthopyroxene.

The Mössbauer spectrum of orthopyroxene, near the ferrosilite end-member composition, consists of two slightly and asymmetrically separated ferrous doublets. The outer doublet results from $\mathrm{Fe}^{2+}$ in the octahedrally coordinated M1 site of the orthopyroxene structure and the inner doublet results from $\mathrm{Fe}^{2+}$ in the more distorted M2 structural site. The evidence for this assignment and a summary of previous orthopyroxene Mössbauer spectra is given by Bancroft [14]. For the samples measured here, the average isomer shifts and quadrupole splittings $\left(\mathrm{Fe}\right.$ in $\mathrm{M} 1 I S_{\mathrm{Pd}}=0.97 \mathrm{~mm} / \mathrm{s}, Q s=2.50 \mathrm{~mm} / \mathrm{s} ; \mathrm{Fe}$ in M2 $I S_{\mathrm{Pd}}=0.92 \mathrm{~mm} / \mathrm{s}, Q_{s}=1.92 \mathrm{~mm} / \mathrm{s}$ ) are closely similar to previously reported values. Observed peak widths varied slightly from $0.29 \mathrm{~mm} / \mathrm{s}$ for both the inner and outer doublet at pure $\mathrm{FeSiO}_{3}$ to 0.30 for the inner and 0.33 for the outer doublet at 10 mole \% Mn component.

Site occupancies of $\mathrm{Fe}^{2+}$ were calculated from the fitted spectral peak areas assuming equal recoil-free fractions for the two sites. The occupancy estimates and their least-squares fitting errors for each com- 
TABLE 3

Microprobe analy ses of run products for 5 mole $\% \mathrm{Rh}_{\mathrm{ss}}$ and $\mathrm{Te}_{\mathrm{ss}}$ starting composition

\begin{tabular}{|c|c|c|c|c|c|c|c|c|}
\hline $\begin{array}{l}\text { Run No. } \\
\text { Temperature } \\
\left({ }^{\circ} \mathrm{C}\right)\end{array}$ & $\begin{array}{l}62 \text { Opx } \\
750\end{array}$ & $\begin{array}{l}62 \text { Oliv } \\
750\end{array}$ & $\begin{array}{l}64 \text { Opx } \\
750\end{array}$ & $\begin{array}{l}64 \text { Oliv } \\
750\end{array}$ & $\begin{array}{l}55 \text { Opx } \\
800\end{array}$ & $\begin{array}{l}55 \text { Oliv } \\
800\end{array}$ & $\begin{array}{l}58 \text { Opx } \\
800\end{array}$ & \\
\hline $\mathrm{SiO}_{2}$ & 46.9 & 30.6 & 46.5 & 30.5 & 46.8 & 30.3 & 45.9 & \\
\hline $\mathrm{MnO}$ & 2.8 & 3.2 & 2.8 & 3.3 & 2.7 & 3.2 & 2.7 & \\
\hline $\mathrm{FeO}$ & 51.1 & 66.0 & 50.9 & 65.8 & 51.1 & 66.4 & 50.7 & \\
\hline Total & $\overline{100.8}$ & 99.8 & $\overline{100.2}$ & 99.6 & $\overline{100.6}$ & 99.9 & $\overline{99.3}$ & \\
\hline $\mathrm{Si}$ & 2.04 & 1.04 & 2.04 & 1.0 & 2.04 & 1.03 & 2.03 & \\
\hline $\mathrm{Mn}$ & 0.10 & 0.09 & 0.10 & 0.09 & 0.10 & 0.09 & 0.10 & \\
\hline $\mathrm{Fe}$ & 1.86 & 1.87 & 1.86 & 1.87 & 1.86 & 1.88 & 1.87 & \\
\hline Run No. & 58 Oliv & $63 \mathrm{Opx}$ & 70 Oliv & $57 \mathrm{Opx}$ & 57 Oliv & $60 \mathrm{Opx}$ & 1133 Opx & \\
\hline $\begin{array}{l}\text { Temperature } \\
\left({ }^{\circ} \mathrm{C}\right)\end{array}$ & 800 & 850 & 850 & 900 & 900 & 900 & 900 & \\
\hline $\mathrm{SiO}_{2}$ & 30.4 & 46.6 & 30.4 & 46.4 & 31.3 & 46.6 & 45.6 & \\
\hline $\mathrm{MnO}$ & 3.2 & 2.7 & 3.5 & 2.8 & 3.0 & 2.7 & 3.1 & \\
\hline $\mathrm{FeO}$ & 66.2 & 51.1 & 66.1 & 51.1 & 66.4 & 51.1 & 51.3 & \\
\hline Total & $\overline{99.8}$ & $\overline{100.4}$ & $\overline{100.0}$ & $\overline{100.3}$ & $\overline{99.7}$ & $\overline{100.4}$ & $\overline{100.0}$ & \\
\hline $\mathrm{Si}$ & 1.03 & 2.04 & 1.03 & 2.02 & 1.03 & 2.03 & 2.00 & \\
\hline $\mathrm{Mn}$ & 0.09 & 0.10 & 0.10 & 0.11 & 0.09 & 0.10 & 0.12 & \\
\hline $\mathrm{Fe}$ & 1.88 & 1.87 & 1.87 & 1.87 & 1.88 & 1.87 & 1.88 & \\
\hline Run No. & 1133 Oliv & 68 Opx & 68 Opx & 69 Opx & 69 Oliv & 56 Oliv & 59 Opx & 59 Oliv \\
\hline $\begin{array}{l}\text { Temperature } \\
\left({ }^{\circ} \mathrm{C}\right)\end{array}$ & 900 & 950 & 950 & 950 & 950 & 1000 & 1000 & 1000 \\
\hline $\mathrm{SiO}_{2}$ & 29.8 & 46.3 & 30.7 & 46.1 & 30.6 & 30.1 & 45.5 & 30.3 \\
\hline $\mathrm{MnO}$ & 2.7 & 2.8 & 3.1 & 2.9 & 3.1 & 3.5 & 2.9 & 3.1 \\
\hline $\mathrm{FeO}$ & 67.5 & 51.2 & 66.9 & 51.3 & 66.3 & 67.1 & 51.9 & 67.0 \\
\hline Total & $\overline{100.0}$ & $\overline{100.3}$ & $\overline{100.7}$ & $\overline{100.3}$ & $\overline{100.0}$ & $\overline{100.8}$ & $\overline{100.3}$ & $\overline{100.4}$ \\
\hline $\mathrm{Si}$ & 1.01 & 2.02 & 1.03 & 2.02 & 1.03 & 1.02 & 1.99 & 1.02 \\
\hline $\mathrm{Mn}$ & 0.08 & 0.11 & 0.09 & 0.11 & 0.09 & 0.10 & 0.11 & 0.09 \\
\hline $\mathrm{Fe}$ & 1.91 & 1.87 & 1.88 & 1.87 & 1.88 & 1.88 & 1.90 & 1.89 \\
\hline
\end{tabular}

position are given in Table 5. The equal occupancy, within experimental error, of the two sites for the pure iron end-member lends confidence in the assumption of equal recoil-free fractions. The spectra are of sufficient quality that the probable errors in site occupancy, even considering small additional systematic errors, are only a few percent of the amount of iron present. Mn occupancies and any resulting Mn site preference, however, rests on the difference between the iron contents of the two sites. As these differences are small in all cases and only slightly larger than the estimated fitting imprecision, a Mn site preference, if any, is not well determined by these data. As shown in Table 5, all the spectra are consistent with a random distribution of $\mathrm{Mn}$ between the M1 and M2 orthopyroxene sites. The deviations of the fitted results from those expected in the case of complete ordering of $\mathrm{Mn}$ in either the $\mathrm{M} 2$ or the M1 site are generally greater and probably beyond reasonable experimental error.

In addition to site occupancies, the activity of fayalite component in tephroite solid solution and 
TABLE 4

Microprobe analyses of run products for 10 mole $\% \mathrm{Rh}_{\mathrm{ss}}$ and $\mathrm{Te}$ ss starting composition

\begin{tabular}{|c|c|c|c|c|c|c|c|}
\hline $\begin{array}{l}\text { Run No. } \\
\text { Temperature } \\
\left({ }^{\circ} \mathrm{C}\right)\end{array}$ & $\begin{array}{l}80 \text { Opx } \\
750\end{array}$ & $\begin{array}{l}80 \text { Oliv } \\
750\end{array}$ & $\begin{array}{l}790 \mathrm{px} \\
800\end{array}$ & $\begin{array}{l}79 \text { Oliv } \\
800\end{array}$ & $\begin{array}{l}730 \mathrm{px} \\
900\end{array}$ & $\begin{array}{l}78 \text { Oliv } \\
900\end{array}$ & $\begin{array}{l}87 \text { Oliv } \\
900\end{array}$ \\
\hline $\mathrm{SiO}_{2}$ & 44.9 & 29.3 & 45.1 & 29.9 & 44.6 & 29.0 & 45.6 \\
\hline $\mathrm{MnO}$ & 5.4 & 6.5 & 5.4 & 6.6 & 5.3 & 6.5 & 5.5 \\
\hline $\mathrm{FeO}$ & 49.5 & 65.2 & 48.8 & 65.1 & 49.8 & 63.4 & 49.3 \\
\hline Total & 99.8 & $\overline{101.0}$ & 99.3 & $\overline{101.6}$ & 99.7 & 98.9 & $\overline{100.4}$ \\
\hline $\mathrm{Si}$ & 1.98 & 0.99 & 2.00 & 1.00 & 1.97 & 0.99 & 2.00 \\
\hline Mn & 0.20 & 0.19 & 0.21 & 0.19 & 0.20 & 0.19 & 0.21 \\
\hline $\mathrm{Fe}$ & 1.82 & 1.83 & 1.79 & 1.81 & 1.83 & 1.82 & 1.80 \\
\hline $\begin{array}{l}\text { Run No. } \\
\text { Temperature } \\
\left({ }^{\circ} \mathrm{C}\right)\end{array}$ & $\begin{array}{l}87 \text { Oliv } \\
900\end{array}$ & $\begin{array}{l}76 \text { Opx } \\
950\end{array}$ & $\begin{array}{l}82 \text { Oliv } \\
950\end{array}$ & $\begin{array}{l}86 \mathrm{Opx} \\
950\end{array}$ & $\begin{array}{l}86 \text { Oliv } \\
950\end{array}$ & $\begin{array}{l}75 \text { Opx } \\
1000\end{array}$ & $\begin{array}{l}81 \text { Oliv } \\
1000\end{array}$ \\
\hline $\mathrm{SiO}_{2}$ & 28.7 & 44.7 & 30.4 & 44.7 & 29.3 & 44.9 & 29.3 \\
\hline $\mathrm{MnO}$ & 6.2 & 5.4 & 7.1 & 5.4 & 6.2 & 5.3 & 6.9 \\
\hline $\mathrm{FeO}$ & 64.4 & 49.7 & 63.0 & 48.3 & 64.8 & 49.8 & 64.0 \\
\hline Total & 99.3 & 99.8 & 100.5 & 98.4 & 100.3 & 100.0 & 100.2 \\
\hline $\mathrm{Si}$ & 0.98 & 1.97 & 1.02 & 1.99 & 0.99 & 1.97 & 1.00 \\
\hline $\mathrm{Mn}$ & 0.18 & 0.20 & 0.20 & 0.21 & 0.18 & 0.20 & 0.20 \\
\hline $\mathrm{Fe}$ & 1.84 & 1.83 & 1.78 & 1.80 & 1.83 & 1.83 & 1.80 \\
\hline
\end{tabular}

the distribution coefficient $\left(K_{D}\right)$ for Fe-Mn between olivine and orthopyroxene must also be known to properly evaluate the mixing properties of $\mathrm{MnSiO}_{3}$ in $\mathrm{FeSiO}_{3}$ from the experimental data presented. These variables are either unknown or are only poorly defined, although the site-occupancy data are of some limited value. The Mössbauer spectra of the run products are consistent with a random distribution of $\mathrm{Mn}$ in the M2 and M1 sites of orthopyroxene. Yet in natural materials, Mn shows a strong preference for the M2 site in orthopyroxene. Because the inferred mixing parameters will be dependent on site occupancies, the differences between experimental and natural materials must be considered. Because of uncertainties in $K_{D}$, the activity of fayalite component in Fe-Mn olivines, and site occupancies, the existing data are insufficient to unambiguously define the mixing parameters of $\mathrm{Fe}-\mathrm{Mn}$ orthopyroxene solutions. However, the data do allow calculation of models that make specific predictions about $K_{D}$ and Fe-Mn mixing parameters in orthopyroxene, which can be tested in future experiments. Table 6 shows models calculated to demonstrate certain features of Fe-Mn orthopyroxene mixing. * Models $1 \mathrm{a}$ and $1 \mathrm{~b}$ show calculated activity coefficients for $\mathrm{FeSiO}_{3}$ component in orthopyroxene $\left(\gamma_{\mathrm{FeSiO}_{3}}^{\mathrm{opx}}\right)$ assuming that the $K_{D}$

\footnotetext{
* The models have been calculated assuming an ordered and disordered pyroxene where activity of ferrosilite in the orthopyroxene $\left(a{ }_{\mathrm{FeSiO}} \mathrm{op}\right)$ is given by $\left(\gamma_{\mathrm{FeSiO}}^{\mathrm{opx}} X_{\mathrm{Fe}}^{\mathrm{opx}}\right)^{2}$ for the disordered case and by $\gamma_{\mathrm{FeSiO}} \mathrm{pex}_{3}\left(1-X_{\mathrm{Mn}}^{\mathrm{M} 2}\right)$ for the ordered case. The activity of fayalite in olivine $(a \mathrm{Fa})$ is calculated as $\left(\gamma \mathrm{Fe}_{2} \mathrm{SiO}_{4} X_{\mathrm{Fe}}^{\mathrm{oliv}}\right)^{2}$ in all cases. $\Delta P$ is then calculated:

$\Delta P \simeq \frac{-R T(41.84)}{\Delta V_{P, T}} \ln \left(a_{\mathrm{Fa}}^{\mathrm{oliv}} / a_{\mathrm{Fs}}^{\mathrm{opx}}\right)$
}

for the reactions:

$\mathrm{Fe}_{2-x} \mathrm{Mn}_{x} \mathrm{SiO}_{4}+\mathrm{SiO}_{2}=2 \mathrm{Fe}_{1-y} \mathrm{Mn}_{y} \mathrm{SiO}_{3}$
(disordered pyroxene)

$\mathrm{Fe}_{2-x} \mathrm{Mn}_{x} \mathrm{SiO}_{4}+\mathrm{SiO}_{2}=\mathrm{Fe}_{2-y} \mathrm{Mn}_{y} \mathrm{Si}_{2} \mathrm{O}_{6}$

(ordered pyroxene) 


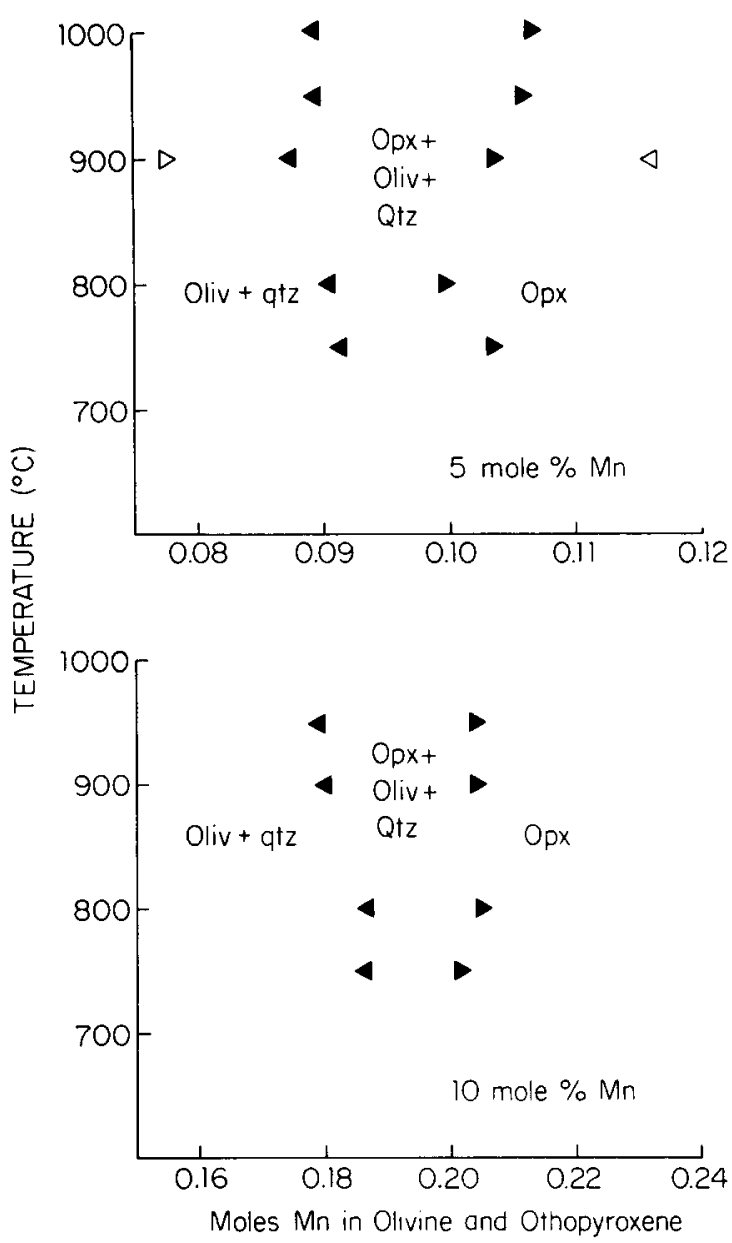

Fig. 3. $T$ - $X$ projection of compositions of coexisting Fe-Mn olivines and pyroxenes in run products as determined by electron mictoprobe analyses (see Table 3 and 4 ). $\leftrightarrow$ indicate the final compositions of olivine and orthopyroxene with starting composition of Fa95 $\mathrm{Te}_{5}$ and $\mathrm{Fs}_{95} \mathrm{Rh}_{5} . \triangleright \Delta$ indicate the final compositions of olivine and orthopyroxene with starting composition of $\mathrm{Fa}_{100} \mathrm{Te}_{0}$ and $\mathrm{Fs}_{90} \mathrm{Rh}_{10}\left(\mathrm{Fs}_{95} \mathrm{Rh}_{5}\right.$ bulk composition). The abscissa shows moles $\mathrm{Mn} / 2(\mathrm{Fe}+\mathrm{Mn})$. is independent of $P$ and $T$ for a disordered (model $1 \mathrm{a})$ and completely ordered (model $1 \mathrm{~b}$ ) pyroxene and assumes further that fayalite-tephroite solid solutions are ideal $\left(\gamma_{\mathrm{Fe}_{2} \mathrm{SiO}_{4}}^{\mathrm{Oliv}}=1\right)$ for models $1 \mathrm{a}$ and $1 \mathrm{~b}$. These constant $-K_{D}$ models require that either $\gamma_{\mathrm{FeSiO}}^{\mathrm{opx}}$ decreases with decreasing $T$ or, in the event $\mathrm{Fe}-\mathrm{Mn}$ olivine solutions are also somewhat non-ideal (1c),

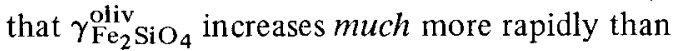
$\gamma \gamma_{\mathrm{FeSiO}} \mathrm{opx}_{3}$ with decreasing $T$. Greater deviations from ideality might be predicted for $\mathrm{Fe}-\mathrm{Mn}$ pyroxenes because of the substantial miscibility gap between $\mathrm{FeSiO}_{3}$ and $\mathrm{MnSiO}_{3}$, compared to $\mathrm{Fe}-\mathrm{Mn}$ olivines for which there is complete solid solution between $\mathrm{Fe}_{2} \mathrm{SiO}_{4}$ and $\mathrm{Mn}_{2} \mathrm{SiO}_{4}$. However, that $\mathrm{Fe}-\mathrm{Mn}$ pyroxenes should become more ideal at lower temperature or that the non-ideality of olivine increase more rapidly than orthopyroxene with decreasing temperature seem somewhat unlikely based on data of other silicate solutions. Models $2 \mathrm{a}$ and $2 \mathrm{~b}$ show that if $\mathrm{Fe}-\mathrm{Mn}$ solutions in orthopyroxene and olivine are ideal, or nearly so, a model with a temperature-dependent $K_{D}$ might fit the data. Unfortunately the required $K_{D}$ values are near the lower limit allowed by the data. At $900^{\circ} \mathrm{C}$, the inferred models with $K_{D}$ 's of $1.18(2 \mathrm{a})$ and $1.15(2 \mathrm{~b})$ are permitted by the data only if errors in the microprobe data are considered. The difference between $K_{D}$ of 1.15 and 1.20 (the lower half-reversal of the $K_{D}$ at $900^{\circ} \mathrm{C}$ ) is equivalent to a difference of $X_{\mathrm{Fe}}^{\mathrm{opx}}= \pm 0.002$ for $\mathrm{Fe}+\mathrm{Mn}=$ 2.0 , which is beyond the accuracy and precision of the microprobe analyses used to infer the $K_{D}$. Nevertheless the $K_{\mathrm{D}}$ 's required by models $2 \mathrm{a}$ and $2 \mathrm{~b}$ are significantly below typical values $(1.3-1.4)$ obtained from natural pairs $[6-8]$ that appear to have equili-

TABLE 5

Iron site occupancies in $\mathrm{Fe}, \mathrm{Mn}$ orthopyroxenes from Mössbauer spectra

\begin{tabular}{|c|c|c|c|c|c|c|}
\hline \multirow[t]{2}{*}{ Composition } & \multirow{2}{*}{$\begin{array}{l}\text { Temperature } \\
\left({ }^{\circ} \mathrm{C}\right)\end{array}$} & \multicolumn{2}{|c|}{$\mathrm{Fe}^{2+}$ content } & \multirow[t]{2}{*}{ Random } & \multicolumn{2}{|c|}{ Deviation from } \\
\hline & & M1 & M2 & & $\mathrm{Mn}$ in $\mathrm{M} 2$ & $\mathrm{Mn}$ in $\mathrm{M} 1$ \\
\hline $\mathrm{Fe}_{1.00}$ & 900 & 0.99 (1) & $1.01(1)$ & $1 \sigma$ & - & - \\
\hline $\mathrm{Fe}_{0.95} \mathrm{Mn}_{0.05}$ & 750 & $0.98(1)$ & $0.92(1)$ & $3 \sigma$ & $2 \sigma$ & $8 \sigma$ \\
\hline $\mathrm{Fe}_{0.95} \mathrm{Mn}_{0.05}$ & 900 & $0.98(1)$ & $0.92(1)$ & $3 \sigma$ & $2 \sigma$ & $8 \sigma$ \\
\hline $\mathrm{Fe}_{0.90} \mathrm{Mn}_{0.10}$ & 750 & $0.88(2)$ & $0.92(2)$ & $2 \sigma$ & $8 \sigma$ & $5 \sigma$ \\
\hline $\mathrm{Fe}_{0.90} \mathrm{Mn}_{0.10}$ & 900 & $0.92(1)$ & $0.88(1)$ & $2 \sigma$ & $6 \sigma$ & $9 \sigma$ \\
\hline
\end{tabular}


TABLE 6

Activity models for $\mathrm{Fe}-\mathrm{Mn}$ pyroxenes

Constant $K_{D}$ models

\begin{tabular}{|c|c|c|c|c|c|c|}
\hline \multirow{4}{*}{$\begin{array}{l}\text { Temperature } \\
\left({ }^{\circ} \mathrm{C}\right)\end{array}$} & \multicolumn{2}{|l|}{ Model la } & \multicolumn{2}{|l|}{ Model 1b } & \multicolumn{2}{|l|}{ Model 1c } \\
\hline & $K_{D}=1.2$ & $K_{D}=1.4$ & $K_{D}=1.2$ & $K_{D}=1.4$ & \multirow{2}{*}{\multicolumn{2}{|c|}{$\begin{array}{l}K_{D}=1.4 \\
\text { Mn ordered in opx }\end{array}$}} \\
\hline & \multicolumn{2}{|c|}{ Mn disordered in opx } & \multicolumn{2}{|c|}{ Mn ordered in opx } & & \\
\hline & $\gamma_{\mathrm{FeSiO}_{3}}^{\mathrm{opx}}$ & $\gamma_{\mathrm{FeSiO}_{3}}^{\text {opx }}$ & $\gamma_{\mathrm{FeSiO}_{3}}^{\text {opx }}$ & $\gamma_{\mathrm{FeSiO}_{3}}^{\mathrm{opx}}$ & $\gamma_{\mathrm{FeSiO}_{3}}^{\mathrm{opx}}$ & $\gamma_{\mathrm{Fe}_{2} \mathrm{SiO}_{4}}^{\mathrm{oliv}}$ \\
\hline 700 & 0.998 & 1.005 & 0.999 & 1.014 & 1.026 & 1.006 \\
\hline 800 & 1.000 & 1.007 & 1.002 & 1.017 & 1.025 & 1.004 \\
\hline 900 & 1.001 & 1.008 & 1.005 & 1.020 & 1.024 & 1.002 \\
\hline 1000 & 1.003 & 1.010 & 1.007 & 1.023 & 1.023 & 1.000 \\
\hline \multicolumn{7}{|c|}{ Variable $K_{D}$ models assuming $\gamma_{\mathrm{FeSiO}_{3}}^{\mathrm{opx}}=\gamma_{\mathrm{Fe}_{2} \mathrm{SiO}_{4}}^{\text {oliv }}=1$} \\
\hline \multirow[t]{2}{*}{$\begin{array}{l}\text { Temperature } \\
\left({ }^{\circ} \mathrm{C}\right)\end{array}$} & \multicolumn{2}{|c|}{$\begin{array}{l}\text { Model } 2 \mathrm{a} \\
\text { Mn disordered in opx }\end{array}$} & \multicolumn{2}{|c|}{$\begin{array}{l}\text { Model } 2 b \\
\text { Mn ordered in opx }\end{array}$} & & \\
\hline & \multicolumn{2}{|l|}{$K_{D}$} & \multicolumn{2}{|l|}{$K_{D}$} & & \\
\hline 700 & \multicolumn{2}{|l|}{1.26} & \multicolumn{2}{|l|}{1.21} & & \\
\hline 800 & \multicolumn{2}{|l|}{1.21} & \multicolumn{2}{|l|}{1.18} & & \\
\hline 900 & \multicolumn{2}{|l|}{1.18} & \multicolumn{2}{|l|}{1.15} & & \\
\hline 1000 & \multicolumn{2}{|l|}{1.17} & \multicolumn{2}{|l|}{1.14} & & \\
\hline \multicolumn{7}{|c|}{ Variable $K_{D}$ models assuming $\gamma_{\mathrm{FeSiO}_{3}}^{\mathrm{opx}}=1.007 \gamma_{\mathrm{Fe}_{2} \mathrm{SiO}_{4}}^{\text {oliv }}=1$} \\
\hline $\begin{array}{l}\text { Temperature } \\
\left({ }^{\circ} \mathrm{C}\right)\end{array}$ & \multicolumn{2}{|c|}{$\begin{array}{l}\text { Model 3a } \\
\text { Mn disordered in opx }\end{array}$} & \multicolumn{2}{|c|}{$\begin{array}{l}\text { Model 3b } \\
\text { Mn ordered in opx }\end{array}$} & & \\
\hline- & \multicolumn{2}{|c|}{$K_{D}$} & \multicolumn{2}{|l|}{$K_{D}$} & & \\
\hline 700 & \multicolumn{2}{|l|}{1.46} & \multicolumn{2}{|l|}{1.32} & & \\
\hline 800 & \multicolumn{2}{|l|}{1.40} & \multicolumn{2}{|l|}{1.27} & & \\
\hline 900 & \multicolumn{2}{|l|}{1.38} & \multicolumn{2}{|l|}{1.24} & & \\
\hline 1000 & \multicolumn{2}{|l|}{1.35} & \multicolumn{2}{|l|}{1.21} & & \\
\hline
\end{tabular}

brated between 750 and $850^{\circ} \mathrm{C}$. It is possible that components outside the $\mathrm{Fe}_{2} \mathrm{SiO}_{4}-\mathrm{Mn}_{2} \mathrm{SiO}_{4}-\mathrm{SiO}_{2}$ system are affecting the $K_{D}$ of natural coexisting phases, causing them to appear slightly higher than the synthetic phases. If the equilibrium $K_{D}$ is larger, perhaps $1.35 \pm 0.05$, then models $3 \mathrm{a}$ or $3 \mathrm{~b}$ might fit the data. These models require that $K_{D}$ increase with decreasing $T$ and that Fe-Mn orthopyroxene be somewhat non-ideal. Similar but more complicated models wherein $\gamma_{\mathrm{FeSiO}_{3}}^{\text {opx }}$ and $\gamma_{\mathrm{Fe}_{2} \mathrm{SiO}_{4}}^{\text {oliv }}$ vary with temperature and $\gamma_{\mathrm{FeSiO}_{3}}^{\mathrm{opx}}>\gamma_{\mathrm{Fe}_{2} \mathrm{SiO}_{4}}$ can be constructed. But any such model yet considered requires an increase in $K_{D}$ with decreasing temperature. Our data allow changes in $K_{D}$ with temperature but tighter reversals are necessary to confirm or deny them. Based on the present experimental data and data from natural minerals, it would appear that the mixing of 10 mole $\% \mathrm{MnSiO}_{3}$ in $\mathrm{FeSiO}_{3}$ may be somewhat non-ideal. However, nothing definitive can be stated without tighter reversals of $K_{D}^{\text {opx-oliv }}$ Mn-Fe and accurate activity data for fayalite-tephroite solid solutions.

\section{Application in field areas}

Manganese is not commonly the most significant impurity affecting the stability of Fe-rich ortho- 
pyroxenes. Typical proportions of $\mathrm{MnSiO}_{3}$ in ferrosilite-rich pyroxenes range between 1 and 4 mole $\%$ as a cursory look at analyses of pyroxenes from field areas such as the Adirondacks [1], Nain [6], Minnesota [7], and the Labrador Trough [9] will show. In these areas, pressures inferred from the orthopyroxene barometer can be revised downward to account for the effect of manganese, although the magnitude of the correction will be small. Unfortunately, pressures in some of these areas might still be somewhat uncertain because of the uncalibrated effect of other components such as $\mathrm{Ca}, \mathrm{Ti}, \mathrm{Al}$, and $\mathrm{Fe}^{3+}$. In the Adirondacks, there is typically less than 3 mole \% rhodonite in orthopyroxene and tephroite in fayalitic olivine, requiring $<0.35 \mathrm{kbar}$ correction. However, there are a few field areas in which ferrosilite-rich pyroxenes and/or fayalitic olivine + quartz have significant amounts of $\mathrm{Mn}$. Frisch and Bridgwater [8] describe orthopyroxene-olivine-quartz assemblages from South Greenland with up to 6 mole $\% \mathrm{MnSiO}_{3}$ in the orthopyroxene. Pressures of 3.9 to $5.4 \mathrm{kbar}$ were estimated (for temperatures of 750$900^{\circ} \mathrm{C}$ ), but the writers noted that the pressures might be in error because of the effects of components outside the $\mathrm{Fe}_{2} \mathrm{SiO}_{4}-\mathrm{Mg}_{2} \mathrm{SiO}_{4}-\mathrm{SiO}_{2}$ system. The experimental work described here and in the preceding paper indicates that emplacement pressures for the intrusions described by Frisch and Bridgwater are 1-2 kbar lower than previously estimated.

In the Lofoten area of Norway, Krogh [4] and Ormaasen [10] report Fe-rich orthopyroxenes where $\mathrm{Mn}$ is the major diluent. In fact, a manganoan orthopyroxene that coexists with pyroxferroite reported by Krogh [4] is essentially $\mathrm{Fs}_{75} \mathrm{Rh}_{22}$, with all other components making up only 3 mole \%. Extrapolation of our data for this pyroxene requires minimum pressures of approximately $9 \mathrm{kbar}$ at $800^{\circ} \mathrm{C}$ or 10.5 kbar at $950^{\circ} \mathrm{C}$. In similar rocks less than $70 \mathrm{~km}$ away from those reported by Krogh, Ormaasen reports orthopyroxenes $\left(\mathrm{Fe}_{87-91} \mathrm{Rh}_{5-8} \mathrm{En}_{1-2} \mathrm{Wo}_{1-2}\right)$ coexisting with fayalitic olivine + quartz in textures which suggest that orthopyroxene is growing at the expense of olivine + quartz. Our data require pressures near $8 \mathrm{kbar}$ at $700^{\circ} \mathrm{C}$ or $9 \mathrm{kbar}$ at $800^{\circ} \mathrm{C}$; these pressures are somewhat lower than those previously estimated. Other Fe-rich orthopyroxenes with significant rhodonite solid solution have been reported by Tsuru and Henry [11], Saxen [12], and Sundius [13], but they contain relatively large amounts of enstatite, wollastonite, and tschermak's component, which make pressure estimates uncertain. Experimental calibration of the effect of these other components would be useful.

\section{Acknowledgements}

The writers are grateful for and acknowledge the support of the Geochemistry Section of the National Science Foundation grants EAR76-22330 and EAR78-16413 to A.L.B., EAR75-22388 and EAR7823568 to E.J.E., DES74-19918 to W.A.D., Geological Society of America grant No. 2168-77 to S.R.B. and the University of Michigan, Turner Funds grants to S.R.B. The writers wish to thank Dr. Jack C. Allen (Department of Geology and Geography, Bucknell University) and Mr. Robert Jones (Department of Earth and Space Sciences, UCLA) for their assistance in several aspects of this research. Mr. Derwin Bell drafted the line drawings.

\section{References}

1 S.R. Bohlen, E.J. Essene and A.L. Boettcher, Reinvestigation and application of olivine-quartz-orthopyroxene barometry, Earth Planet. Sci. Lett. 47 (1980) 1.

2 D. Smith, Stability of iron-rich orthopyroxene, Carnegie Inst. Washington Yearb. 68 (1969) 229.

3 D. Smith, Stability of the assemblage iron-rich orthopyroxene-olivine-quartz, Am. J. Sci. 271 (1971) 370.

4 E.J. Krogh, Origin and metamorphism of iron formations and associated rocks, Lofoten-Vesterålen, N. Norway, I. The Vestpolltind Fe-Mn deposit, Lithos 10 (1977) 243.

5 L.H. Cohen and W. Klement, Jr., High-low quartz inversion: determination to 35 kilobars, J. Geophys. Res. 72 (1967) 4245.

$6 \mathrm{~J} . \mathrm{H}$. Berg, Regional geobarometry in the contact aureoles of the anorthositic Nain Complex, Labrador, J. Petrol. 18 (1977) 399.

7 B. Bonnichsen, Metamorphic pyroxenes and amphibolites in the Biwabik Iron Formation, Dunka River Area, Minne. sota, Mineral. Soc. Am. Spec. Paper 2 (1969) 217.

$8 \mathrm{~T}$. Frisch and D. Bridgwater, Iron- and manganese-rich minor intrusions emplaced under late-orogenic conditions in the Proterozoic of South Greenland, Contrib. Mineral. Petrol. 57 (1976) 25.

9 C. Klein, Regional metamorphism of Proterozoic iron formation, Labrador Trough, Canada, Am. Mineral. 63 (1978) 898 . 
10 D.E. Ormaasen, Petrology of the Hopen mangerite-charnockite intrusion, Lofoten, North Norway, Lithos 10 (1978) 291.

$11 \mathrm{~K}$. Tsuru and N. Henry, An iron rich optically positive hypersthene from Manchuria, Mineral. Mag. 24 (1937) 527.

12 M. Saxen, Om manganiarnmalmfyndighetene i Vittinki, Fennia 45 (1925) 18.
13 N. Sundius, Uber den sogenannten Eisenathophyllit der Eulysite, Arb. Sver. Geol. Unders. 26 (1932) 2.

14 G.M. Bancroft, Mössbauer Spectroscopy (McGraw-Hill, London, 1973) 165-177; 212-221.

15 S. Ruby, Mössbauer Effect Methodology, Vol. 8, I.J. Gruverman, ed. (Plenum Press, New York, N.Y.) 263276. 